\title{
Preparation of $\mathrm{HA} / \mathrm{TiO}_{2}$ Biological Coating on Titanium Alloy
}

\author{
H.P. Shao, S.J. Wu, T. Lin, Z.M. Guo \\ Institute for Advanced Materials \& Technology \\ University of Science and Technology Beijing \\ Beijing 100083, China
}

\begin{abstract}
In this paper, hydroxyapatite and $\mathrm{TiO}_{2}$ biological coatings on TC4 titanium alloy substrate was prepared by electrophoretic deposition (EPD) method. The coatings were characterized by scanning electron microscopy (SEM). By subsequent different conditions of heat treatment process (vacuum and high purity argon), corrosion resistance of composite biological coatings were investigated by potentiodynamic polarization curves method. The results showed that the coatings were dense and can be tightly combined with substrate after sintering when $\mathrm{TiO}_{2}$ content was $10 \mathrm{~g} \cdot \mathrm{L}^{-1}$. Corrosion resistance of specimens treated by heat treatment in argon atmosphere was superior to specimens treated by heat treatment in vacuum.
\end{abstract}

Keywords-electrophoretic deposition; HA; suspension; corrosion resistance; heat treatment

\section{INTRODUCTION}

Hydroxyapatite $\left(\mathrm{HA}, \mathrm{Ca}_{10}\left(\mathrm{PO}_{4}\right)_{6}(\mathrm{OH})_{2}\right)$ is one of the most common types of bioactive ceramic materials, which has the same structure as inorganic of human body bone. It has non-toxic after implantation in the human body and no rejection in vitro owing to its excellent bioactivity and biocompatibility[1-3]. It can stimulate or induce bone tissue growth and can form ceramic materials containing phosphorus and calcium with bone tissue. However, the flexural strength and fracture toughness are lower than those of human compact bone, and the poor mechanical performance has restricted the use in load-bearing parts in the human body [4]. Titanium alloy has excellent properties such as good corrosion resistance, biocompatibility and so on. It can be used in the manufacture of medical apparatus and instruments, prosthesis and auxiliary treatment equipment etc., which is one of the widely used metal implant materials[5-6]. HA coated to titanium alloy surface not only has a good biological activity, but excellent mechanical properties of titanium alloy substrate and good biological properties of HA ceramics, which has become a hot topic of current biomedical materials research[7-8].

In this paper, the different content additives $\mathrm{TiO}_{2}$ were mixed with HA to prepare composite coatings of different content additives and HA on titanium alloy substrate surface by the ultrasonic dispersion and EPD method. The influence of different content $\mathrm{TiO}_{2}$ on HA biological coatings of titanium alloy substrate was studied. By subsequent different conditions heat treatment process, corrosion resistance properties of $\mathrm{HA} / \mathrm{TiO}_{2}$ composite biological coatings on $\mathrm{TC} 4$ titanium alloy surface were studied.

\section{EXPERIMENTAL PROCEDURE}

TC4 titanium alloy substrate cut into $20 \mathrm{~mm} \times 10 \mathrm{~mm} \times 1$ $\mathrm{mm}$ was chosen as samples. The samples were polished and smooth by mechanical grinding. They were putted into acetone for degreasing, rinsed with deionized water to remove surface residual liquid, and they were cleaned in deionized water by ultrasonic dispersion. Afterwards, the samples were treated by $\mathrm{HF}$ solution $100 \mathrm{ml} / \mathrm{L}+\mathrm{HNO}_{3}$ solution $300 \mathrm{ml} / \mathrm{L}$. Finally they were taken out immediately, putted into flowing deionized water and then cleaned in deionized water by ultrasonic dispersion to use for EPD.

The n-butyl alcohol was selected as solvent and triethanolamine was used to adjust $\mathrm{pH}$ value to $7 \sim 8$. HA and $\mathrm{TiO}_{2}$ were mixed fully by different mass ratio. Then a stable suspension can be obtained by ultrasonic stirring after $1 \mathrm{~h}$. Suspension ages for $24 \mathrm{~h}$ can be used for EPD experiment. A stainless steel cylinder was as an anode, titanium alloy substrate as a cathode which was placed in the stainless steel cylinder axis. The distance between cathode and anode was 10 $\mathrm{mm}$, deposition voltage was $30 \mathrm{~V}$ and deposition time was 120 s. After deposition, the samples were dried in air and then stored in desiccators. The dried samples were placed in a tube resistance furnace for heat treatment. This experiment adopted two kinds of environment of heat treatment-vacuum and high purity argon (purity $\geq 99.99 \%$, mass fraction). Heat treatment temperature was $800 \sim 850{ }^{\circ} \mathrm{C}$, heating rate was $5{ }^{\circ} \mathrm{C} \cdot \mathrm{min}^{-1}$, hold for $1 \mathrm{~h}$, then cooled to room temperature in the furnace. The structure characteristics of the coatings were observed and analyzed by SEM. Corrosion resistance of implanted materials was investigated by potentiodynamic polarization curves method.

\section{RESULTS AND DISCUSSIONS}

Figure1 shows the SEM photos of composite biological coatings of TC4 titanium alloy substrate which was made up of different content $\mathrm{TiO}_{2}$ and HA. Shown as in Figure1(a), when $\mathrm{TiO}_{2}$ was $2 \mathrm{~g} \cdot \mathrm{L}^{-1}$ in suspension, much holes existed in the coatings, the structure was loose. Furthermore the binding state between coating and substrate interface was not close and existed obvious boundary. When $\mathrm{TiO}_{2}$ increases gradually, loose structure will be improved to some extent and had no obvious boundary as shown in Figure 1 (a) and (b). On the other hand, when $\mathrm{TiO}_{2}$ content was high $\left(10 \mathrm{~g} \cdot \mathrm{L}^{-1}\right)$, coatings 
were uniform and dense relatively. And thickness of $\mathrm{HA} / \mathrm{TiO}_{2}$ composite biological coatings was about $25 \mu \mathrm{m}$. Between coatings and substrate interface combined closely, there was no obvious boundary. This showed that coatings were dense and can be tightly combined with substrate after sintering when $\mathrm{TiO}_{2}$ content was $10 \mathrm{~g} \cdot \mathrm{L}^{-1}$.

Figure2 showed electrochemical corrosion polarization curves of the coatings which were treated by different conditions of heat treatment process in simulated body fluid. Shown as in the Figure 2, it also experienced a stable passivation phenomenon and a stable and less corrosion current density in the anode region as the voltage increased. Then the corrosion current density increased rapidly due to the breakdown of the passive film. When corrosion potential became high, it re-entered a stable passivation stage.

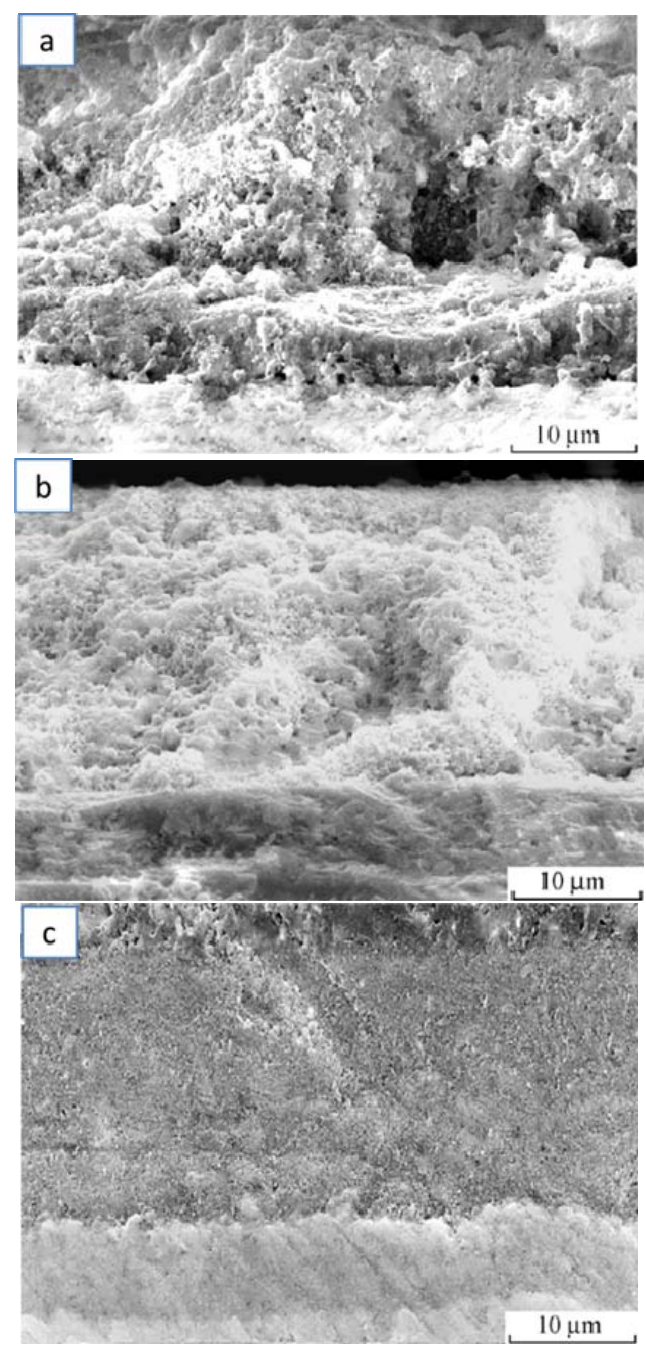

FIGURE I. SEM IMAGES OF CROSS-SECTIONAL OF COMPOSITE COATINGS WITH DIFFERENT CONTENT OF TiO2 AFTER HEAT TREATMENT AT $800{ }^{\circ} \mathrm{C}$ IN VACUUM(a)HA $10 \mathrm{~g} \cdot \mathrm{L}^{-1}+\mathrm{TiO}_{2} 2 \mathrm{~g} \cdot \mathrm{L}^{-1}$; (b) $\mathrm{HA} 10 \mathrm{~g} \cdot \mathrm{L}^{-1}+\mathrm{TiO}_{2} 6 \mathrm{~g} \cdot \mathrm{L}^{-1}$; (c) $\mathrm{HA} 10 \mathrm{~g} \cdot \mathrm{L}^{-1}+\mathrm{TiO}_{2} 10 \mathrm{~g} \cdot \mathrm{L}^{-1}$.

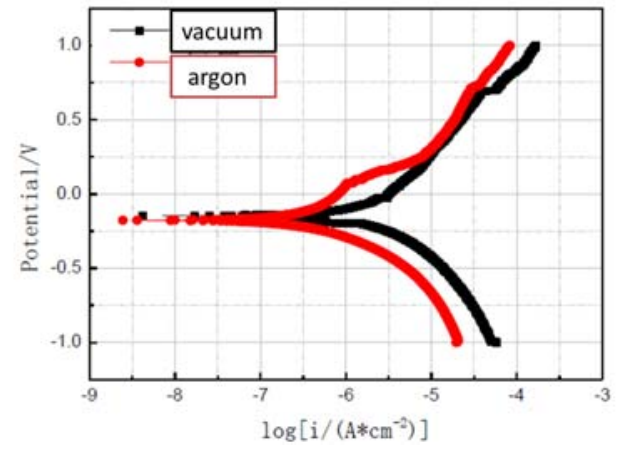

FIGURE II. ELECTROCHEMICAL CORROSION POLARIZATION CURVES OF THE COATINGS WHICH WERE TREATED BY DIFFERENT CONDITIONS OF HEAT TREATMENT ENVIRONMENT IN SIMULATED BODY FLUID.

TABLE I. CORROSION CURRENT AND CORROSION POTENTIAL CORRESPONDED TO DIFFERENT HEAT TREATMENT ENVIRONMENT.

\begin{tabular}{lll}
\hline Sample & $\begin{array}{l}\mathrm{E}_{\text {corr }} \text { vs SCE } \\
/ \mathrm{V}\end{array}$ & $\mathrm{I}_{\text {corr }} / \mu \mathrm{A} \cdot \mathrm{cm}^{-2}$ \\
\hline vacuum & -0.147 & 2.92 \\
argon & -0.178 & 0.845
\end{tabular}

Table 1 was the electrochemical parameters that were obtained by fitting polarization curve data. Shown as in the Table1, corrosion potential had little difference between samples treated by heat treatment in vacuum and samples treated by heat treatment $t$ in argon atmosphere. But the corrosion current density in argon atmosphere was significantly less than the corrosion current density in vacuum, that's to say, the samples treated by heat treatment $t$ in argon atmosphere had a better corrosion resistance

Figure 3 was AC impedance Nyquist diagram (the vertical axis was the imaginary part of the impedance value, the abscissa was the real part of the impedance value) of the coatings were treated by different heat treatment environment. As we can see, capacitive arc radius of samples treated in argon atmosphere was larger than other, and exhibited a better corrosion resistance that also confirms the results of the analysis of polarization curves.

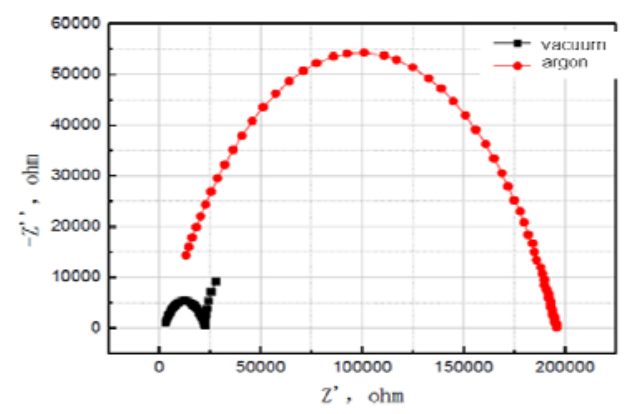

FIGURE III. AC IMPEDANCE NYQUIST DIAGRAM IN DIFFERENT HEAT TREATMENT ENVIRONMENT. 


\section{CONCLUSIONS}

$\mathrm{HA} / \mathrm{TiO}_{2}$ composite biological coatings were prepared successfully by adding additives $\mathrm{TiO}_{2}$ to $\mathrm{HA}$ to form a stable suspension. Thickness of $\mathrm{HA} / \mathrm{TiO}_{2}$ composite biological coatings was about $25 \mu \mathrm{m}$. When $\mathrm{TiO}_{2}$ was $2 \mathrm{~g} \cdot \mathrm{L}^{-1}$, there were some holes existed in the coatings and the structure was loose; when $\mathrm{TiO}_{2}$ content was $10 \mathrm{~g} \cdot \mathrm{L}^{-1}$, the coatings were uniform and dense relatively. Corrosion resistance of specimens were treated by heat treatment in argon atmosphere was superior to specimens were treated by heat treatment in vacuum.

\section{ACKNOWLEDGEMENTS}

This work was financially supported by the National Natural Science Foundation of China (No.51274039) and Production, Education \& Research Project of Guangdong Province (No.2011A090200091).

\section{REFERENCES}

[1] Wang Z C, Ni Y J, Huang J C. Effects of suspension power content on the electrophoretic deposition of hydroxyapatite coatings [J]. Journal of the Chinese Ceramic Society, 2008, 36(5): 626-630.

[2] Lídia Ágata de Sena, Mônica Calixto de Andrade, Alexandre Malta Rossi, Gloria de Almeida Soares. Hydroxyapatite deposition by electrophoresis on titanium sheets with different surface finishing [J]. Journal of Biomedical Materials Research, 2002, 60(1): 1-7.

[3] Byung-Dong Hahn, Jung-Min Lee, Dong-Soo Park, Jong-Jin Choi, Jungho Ryu, Woon-Ha Yoon, Byoung-Kuk Lee, Du-Sik Shin, Hyoun-Ee Kim. Mechanical and in vitro biological performances of hydroxyapatite-carbon nanotube composite coatings deposited on $\mathrm{Ti}$ by aerosol deposition [J]. Acta Biomaterialia, 2009, 5(8): 3205-3214.

[4] Chen F, Lin C J, Wang Z C. The electrophoretic deposition of nano hydroxyapatite coating on titanium surface [J]. Electrochemistry, 2005, 11(1): 67-70.

[5] Shengjiang Wu, Huiping Shao, Ran Wei. Ito. Influences of different surface treatments on titanium substrate to $\mathrm{HA} / \mathrm{TiO}_{2}$ bioactive coatings [J]. Advanced Materials Reaserch, 2014, 893: 508-511.

[6] Yang D H, Shao H P, Fan L P, Lin T, Guo Z M. Porosity and mechanical properties of porous Ti-7.5Mo alloy for medical applications by gelcasting [J]. Journal of University of Science and Techno logy Beijing, 2011, 33(9): 1122-1126.

[7] Boon Sing Ng, Ingegerd Annergren, Andrew M Soutar, K.A. Khoret, Anders E.W. Jarfors. Characterization of a duplex $\mathrm{TiO} 2 / \mathrm{CaP}$ coating on Ti6Al4V for hard tissue replacement [J]. Biomaterials, 2005, 26: 1087-1095.

[8] Huiping Shao, Shengjiang $\mathrm{Wu}$, Tao Lin, Ran Wei. Study of corrosion-resistance on biomedical coating by different surface treatments [J]. Applied Mechanics and Materials, 2014, 563: 391-395. 